American Journal of Environmental Sciences 4 (5): 439-444, 2008

ISSN 1553-345X

(C) 2008 Science Publications

\title{
Managing Air in Olympic Cities
}

\author{
Qing Wen Tian and Peter Brimblecombe \\ School of Environmental Sciences, University of East Anglia, Norwich NR4 7TJ, UK
}

\begin{abstract}
The 21st century Olympic Agenda aims to align itself with the concept of sustainable development and has driven improved environmental quality in host cities, such as the Green Games in Sydney 2000 and the planned Beijing 2008 Games and in London 2012 as the Low Carbon Games. Air quality has long been a concern of Olympic mega-cities, although the air quality plans and strategies have often seemed short-lived and unsustainable in the long term. We have explored air quality data and air pollution control from seven Olympic cities: Mexico City, Los Angeles, Atlanta, Sydney and Athens and also Beijing and London which will host Olympic Games in near future. The study shows that despite a high altitude and air pollution problems, Mexico City had no clear environmental policy in place for the 1968 games. The characteristic smog of Los Angeles raised concerns about athletic performance at the Olympic Games of 1984, but there were limited efforts to tackle the ozone concentration during these games. The 1996 Atlanta Games represents a case where temporary public transport changes were used as a tactic to reduce air pollution. In Sydney a well planned sustainable strategy reduced air pollutants and $\mathrm{CO}_{2}$ emissions in 2000, but Athens' long efforts to improve air quality for the 2004 games were not wholly effective. Even where strategies proved successful the improvements in air quality seem short-lived. Current host cities Beijing and London are developing emission reduction plans. These have clear air quality objectives and are well intentioned. However, the improvements may be too narrow and may not be sustainable in the long term. Our analysis looks at the origins of success and failure and how more coherent improvements might be achieved and what would promote sustainable plans for air quality management at future games. The study illustrates the feedback between air pollution science and policy awareness.
\end{abstract}

Key words: air quality tactics, sustainability, transport strategy

\section{INTRODUCTION}

Olympic Games bring particular attention to cities. Not only must they host athletes, but also visitors and spectators. This means that civic administrators want the host location to appear in its best light. Increasingly environmental issues are relevant to the way visitors perceive cities. Olympic Games are also a time where cities undertake large scale urban renewal, which provides an opportunity for improvement. This has meant that air pollution has become part of the planning process in giving the city a good environment, but air pollution also impinges on athletic performance. Particularly noticeable is that the Olympic Games require fine weather, so in summer this can mean high concentrations of photochemical smog.

This study is about the air quality of Olympic cities and its air quality management during the period of the Games. It explores the approaches to managing the air quality and asks whether these represent a sustainable improvement in environmental quality.
Prior to the 1960's relatively little attention was given to environmental considerations, we would now regard as important, in planning Olympic Games. The 1968 games in Mexico City were especially notable because the altitude provoked a particularly worry about athletic performance at altitude and in a polluted urban area $^{[1]}$. Although Mexico City has become remarkably troubled by smog, fortunately in the 1960s this was less of a problem. However, the choice Los Angeles for the games of 1986 could not fail to provoke concerns about air quality given that photochemical smog was discovered there in the 1950s. The city has come to typify the modern notion of smog. The problems of air pollution this time dogged thoughts about the games.

This concern was still a novel one and it was initially seen to relate only to Los Angles, but gradually the IOC had to recognise a continuing importance environmental consideration. By 1994 the IOC reached a consensus with the United Nations Environment

Corresponding Author: $\quad$ Peter Brimblecombe, School of Environmental Sciences, University of East Anglia, Norwich NR4 7TJ, UK 
Programme (UNEP) in a co-operative agreement that recognised the concept of sustainable development. As a result, the environment has becomes the third pillar of the Olympic charter along with sport and culture.

In 1996 the Atlanta Olympic Games developed transport tactics to improve air quality and traffic congestion during the games. In 1999 the Sport and Environment Commission implemented the Olympic Movement's Agenda 21 which again focussed on sustainable development (IOC Sport and Environment Commission, 2003). The 2000 Sydney Olympic Games became the first host city to follow this Agenda. Sydney released its Environmental Guidelines in 1993. These were prepared by the local Government, Greenpeace and other environmental groups. The 2008 Beijing Green Games and the future London 2012 Low Carbon Games set targets to meet as part of their sustainable environmental goals. Air quality and air quality management as the major environmental problem has been highlighted in the Olympic mega cities (www.olympic.org).

\section{MATERIALS AND METHODS}

Our study planned to assess the air quality control impacts by reviewing previous Olympic host city air quality data and documents. It considers issues which relate to air pollution management. It explores material from historic games: Mexico City's high altitude air pollution, the well-known air pollution in Los Angeles, the success of Sydney's Green Olympics and the recent Athens Olympics. We also look to the future and study preparations for the Olympic in Beijing 2008 and London 2012 and the way in which they have learnt from previous Games. The study compares these individual cases, by considering air pollution in the Olympic cities. It then examines the air pollution control strategies and action plans. Finally, the success is discussed in terms of the outcome in previous Olympic cities. Hopefully the analysis reveals ways in which sustainable air pollution reduction is best achieved in future Olympics.

Air quality planning documents and measurements were gathered from the literature and scientific papers. There are seven Olympic cities that were studied which, involve five historical Olympic cities and two current Olympic cities.

\section{RESULTS AND DISCUSSION}

Mexico City: The monitoring of air pollution in the Mexico City Municipal Area (MCMA) began in the late 1950 s based on some efforts at exploratory monitoring ${ }^{[2]}$, but only in the early 1970s did air quality in Mexico City begin to be widely recognized as a serious problem. Sulfur dioxide was of concern in the MCMA before 1990 and concentrations showed some increase due to urban development, industrial expansion and increases in the vehicle fleet ${ }^{[3]}$. Although there were some worries about athletic performance at the high altitude urban location, there little policy implementation for these 1968 Olympic Games.

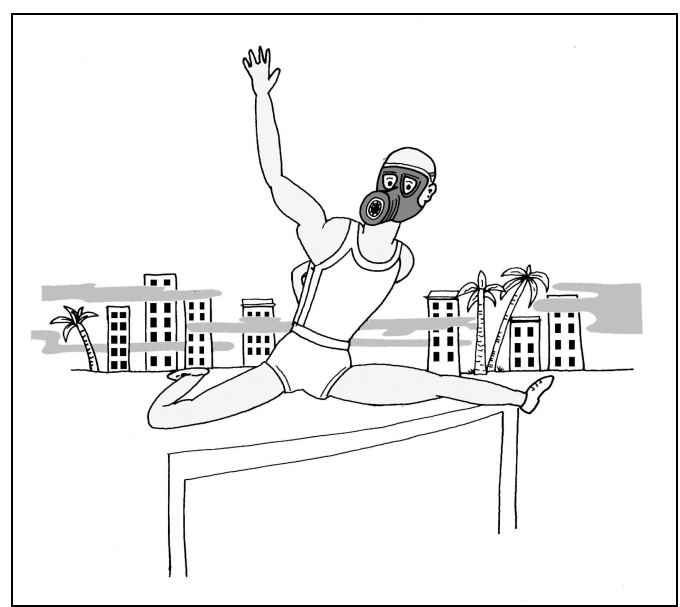

Fig. 1: Sketch from a T-shirt produced for the Los Angeles Olympic Games (drawing by Phillip Judge)

Los Angeles: During the late 1970s and early 1980s, the major secondary pollutants: nitrogen dioxide and ozone and carbon monoxide predominated in Los Angeles air basin. This airshed has long been regarded as typifying the photochemical situation. Although a succession of plans and control measures came as result of legislation such as the Clean Air Act of 1970, non attainment of National Ambient Air Quality Standards remained a problem here for much of the latter part of the $20^{\text {th }}$ century. There were vocal concerns about air pollution and the Olympic Games and this even featured on T-shirts produced at the time which showed an athlete wearing a gas mask and smog winding in and out of the buildings behind (Fig. 1). However, the local government did not put any special plans into effect to tackle the ozone problem during the Olympic period ${ }^{[4]}$.

Atlanta: During 1996 Atlanta Olympic Games, the city faced the task of accommodating the sudden influx of a million of people over a short time period. It required civic authorities to coordinate the travel behaviour of 7.5 million spectators, of which 100,000 were directly associated with the Olympics. Planners devised an extensive multi-modal system of park and ride lots, 
NO

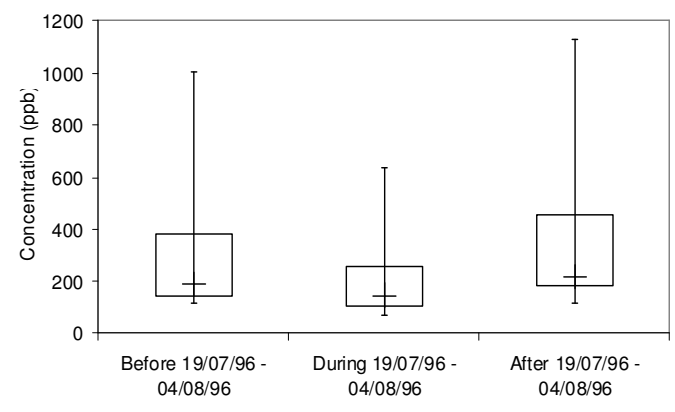

Ozone

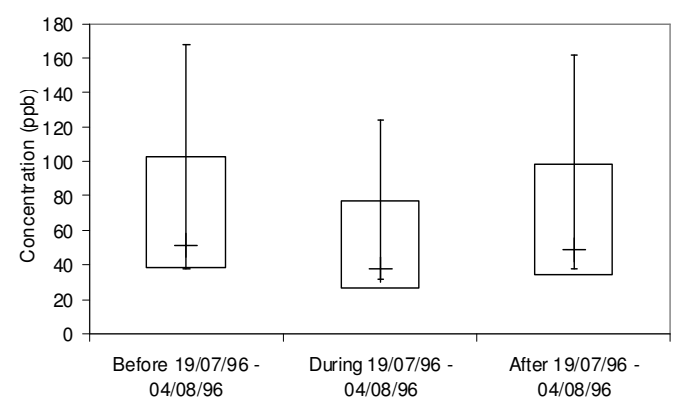

$\mathrm{CO}$
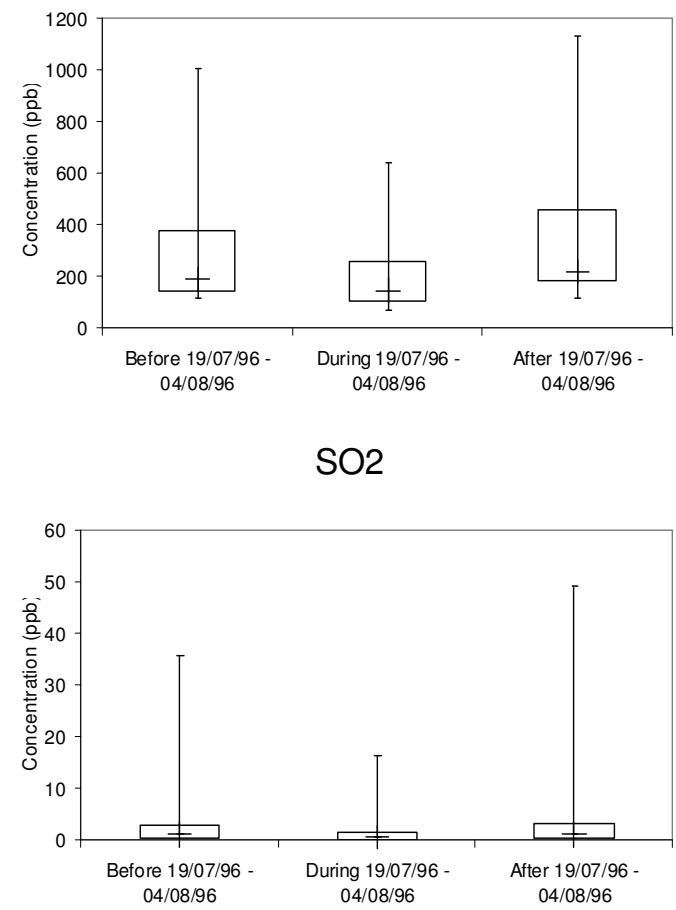

Fig 2: Box and Whisker plot of air pollutants in post, during and after Olympic Games in 1996 Atlanta

buses, light rail and pedestrian corridors that would ferry visitors from as far as 60 miles out to the Olympic venues. Parking in downtown was limited to those directly associated with the Olympics. For those not taking public transport, much still needed to be done to prevent a total standstill on the roads. High-occupancy vehicle lanes were built and downtown employees were educated on transportation demand strategies (TDM). Scare tactics on the horror of the congestion during the Olympics were even used to discourage people from travelling during peak hours. The Olympic Transportation Information System (OTIS), a comprehensive computer database, predicted travel behaviour for every hour over the 17 days of the games.

The Olympics forced Atlanta to address its infrastructure problems and as a result it successfully reduced traffic. As can be seen in Fig. 2 there is evidence that this also reduced air pollution for the duration of the games.

Sydney: In response to the new Olympic environmental guidelines Sydney seriously considered air quality tactics. Two sectors were address during the Olympic planning: energy and transportation (Table 1).
Table 1: Approaches to transport in Sydney

\begin{tabular}{ll}
\hline Transportation & Changes \\
\hline Public transport & $\begin{array}{l}\text { Ticketing system, private } \\
\text { car parking suspend }\end{array}$ \\
Train line extensions & $\begin{array}{l}\text { Railway infrastructure } \\
\text { New freeway link tunnel from the } \\
\text { Road extensions }\end{array}$ \\
city's north to Sydney airport \\
Cark travel & $\begin{array}{l}\text { Park and rid, solar powered } \\
\text { vehicle and ferries }\end{array}$ \\
Cycling and foot & Cycle paths and foot paths \\
\hline
\end{tabular}

In addition, indoor air quality was a concern when developing the Olympic infrastructure. In 1996, the Olympic Co-ordination Authority commissioned an Energy Options Study of 14 possible renewable energy sources for the Olympic site. It "strongly recommended" sources were solar photovoltaic (PV) electricity and natural gas co-generation. Solar PV was installed on the 665 roofs of Athletes' Village and Olympic Venues. Transportation was a significant source of polluting greenhouse gases and the Games created the highest ever continuous demand for passenger transport. Effective transport operations were vital to the smooth running of the Games and to ensure minimal disruption to daily life in Sydney. During the Olympic period standard, $\mathrm{CO}, \mathrm{O}_{3}, \mathrm{SO}_{2}$ and $\mathrm{NO}_{2}$ are 
well remained below the concern levels and only the maximum 1-hour $\mathrm{PM}_{10}$ concentration was higher that the Ambient Air Quality standards.

The indoor air quality was also addressed to achieve reduced air pollutant emissions within Olympic venues. This included careful selection of non-toxic materials, such as natural fibre insulation and non-toxic paints, glues, varnishes, polishes, solvents and cleaning products.

Athens: The 2004 Athens Olympic was the biggest ever and an important opportunity for Greece to show case the Olympics, which had classically been its home. From the start the Greek government was anxious to take scientific advice on issues such as air pollution, drug testing etc. However, there was also a need to ensure that projects were delivered on time, so they did not always pay sufficient attention to the environmental quality ${ }^{[5]}$.

Despite the problems, feedback was the air quality in Athens 2004 was slightly better than anticipated. The improvement was probably the result of transportation and energy control during the Games period.

A new metro line was been built and gas-fuelled buses introduced, such that Athens now has the largest gas-fuelled bus fleet in Europe. More than $€ 3$ billion were spent in public transport (including the extension of metro, introduction of tramways and suburban rail, modernisation of bus and trolley fleets and tripling of bus-only lanes). It is estimated that $50 \%$ of population were using the public transportation system by the end of 2004. It was the intention of Athens Olympic Committee (ATHOC) that all electricity used by related premises and users during the Olympics in 2004 should be generated by renewable, but this was not achievable.

Beijing: The terrain of the Beijing area slopes from the northwest to the south east. Beijing is enclosed tightly by the heavy industry located in every direction around. In the recent decade, urban construction has bloomed such that high buildings stand shoulder by shoulder around the $2^{\text {nd }}$ ring road making Beijing downtown just like a basin.

Annual environmental reports from 1998 to 2005, give the concentrations of $\mathrm{TSP} / \mathrm{PM}_{10}, \mathrm{SO}_{2}, \mathrm{NO}_{\mathrm{x}}, \mathrm{CO}$ and $\mathrm{O}_{3}$ in Beijing (listed in Table 2). Comparing ambient concentrations for 2005 with those in 1998, shows that most pollutants have been declining with the exception of $\mathrm{NO}_{\mathrm{x}}$. It is thought the switch in energy sources in Beijing from coal to petroleum is largely responsible.

The greatly economic progress of the region and increasing fossil fuel derived energy consumption has resulted in large amounts of $\mathrm{NO}_{\mathrm{x}}$ to be emitted into the ambient atmosphere ${ }^{[6]}$.

London: London 2012's central concept is a Low Carbon Games - games that will reduce energy demand and meet it from low carbon and renewable sources. Part of this strategy, as stated in the Candidate File, includes offsetting the unavoidable carbon emissions due to Games-related travel. London 2012 will aim to ensure no net increase in global emissions due to participants flying to the Games in 2012 and to create a direct legacy of clean energy production and social benefits in developing countries. Air travel by national teams, technical officials and Olympic and Paralympic Family members coming to London and travel by members of the organising committee during the seven year preparation phase of the Games, is estimated to account for some 30,000 - 35,000 tonnes of carbon dioxide emissions.

These emissions will be offset by supporting renewable energy projects with strong sustainable development benefits in developing countries. This will be achieved through the purchase and retirement of emission reduction credits and by directly investing in new capacity, which will promote access to clean energy in Least Developed Countries.

The Games are embedded within Agenda 21, yet the summer Olympic Games are typically held in big cities. Such cities often have major problems with air quality and traffic, so municipal governments are encouraged to improve their air quality and traffic by achieving a certain target for the games. These targets normally will be set out as part of the Environmental Management Strategies (Olympic Movement's Agenda 21).

Atlanta became the first Olympic city after the agreement. During the 1996 Olympic period, planners introduced an alternative transportation strategy to reduce air pollution. This non sustainable strategy mainly involved the enforcement of public transport use and encouraging non-peak hour travel. Efforts to reduce traffic congestion during the Olympic Game led to improved air quality. It was associated with a reduction in ozone $\left(\mathrm{O}_{3}\right)$ and other air pollutants. The record (Table 3) shows peak daily $\mathrm{O}_{3}$ concentrations decrease $28 \%$ from $160 \mu \mathrm{g} \mathrm{m}^{-3}$ for the pre-Olympic period to $115 \mu \mathrm{g} \mathrm{m}^{-3}$ during Olympic Game. Atlanta strongly enforced on the temporary transportation restrictions, but after the Games, the congestion and air pollution problems still remain ${ }^{[7]}$.

The Athens Olympics 2004 utilized previous experience and created an Olympic Environmental Alliance which involved all interested parties and stakeholders. It focussed on creating synergies with 
Am. J. Environ. Sci., 4 (5): 439-444, 2008

Table 2: Annual mean concentrations of main air pollutants at Beijing urban sites for the period $1998-2005\left(\mu \mathrm{g} / \mathrm{m}^{3}\right)$

\begin{tabular}{cccccc}
\hline Year & $\mathrm{SO}_{2}$ & $\mathrm{NO}_{2}$ & $\mathrm{PM}_{10}$ & $\mathrm{TSP}$ & $\mathrm{CO}$ \\
\hline 1998 & 120 & 74 & $\mathrm{None}$ & 378 & 3.3 \\
1999 & 80 & 77 & 180 & 364 & 2.9 \\
2000 & 71 & 71 & 162 & 353 & 2.7 \\
2001 & 64 & 71 & 165 & 370 & 2.6 \\
2002 & 67 & 76 & 166 & 373 & 2.5 \\
2003 & 61 & 72 & 141 & None & 2.4 \\
2004 & 55 & 66 & 149 & & 2.2 \\
2005 & 50 & -10.81 & -21.11 & & -39.39 \\
\hline Comparing value & -58.33 & & & \\
in 2005 with that & & & & & \\
in 1998 & & & & & \\
\hline
\end{tabular}

Table 3: The changes in air pollutants concentration in Olympic cities

\begin{tabular}{|c|c|c|c|c|c|c|}
\hline \multirow[b]{2}{*}{ Olympic City } & \multirow{2}{*}{ Data Period } & \multicolumn{5}{|c|}{ Changes of Air Pollutants Concentration } \\
\hline & & $\mathrm{CO} \mathrm{mg} / \mathrm{m}^{3}$ & $\mathrm{NO} 2 \mathrm{ug} / \mathrm{m}^{3}$ & $\mathrm{SO} 2 \mathrm{ug} / \mathrm{m}^{3}$ & $\mathrm{O} 3 \mathrm{ug} / \mathrm{m}^{3}$ & PM $10 \mathrm{ug} / \mathrm{m}^{3}$ \\
\hline $\begin{array}{l}1996 \text { - Atlanta } \\
19 \text { Jul. - } 4 \text { Aug. }\end{array}$ & $\begin{array}{c}\text { Olympic Period } \\
\text { vs pre }\end{array}$ & $\begin{array}{c}\downarrow 18.2 \% \\
1.4 \text { vs } 1.8\end{array}$ & 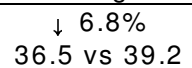 & $\begin{array}{c}\uparrow 21.9 \% \\
11.3 \text { vs } 9.2\end{array}$ & $\begin{array}{c}\downarrow 27.9 \% \\
115.1 \text { vs } 159.6\end{array}$ & $\begin{array}{c}\downarrow 16.1 \% \\
30.8 \text { vs } 36.7\end{array}$ \\
\hline $\begin{array}{l}2000 \text { - Sydney } \\
16 \text { Sep. - } 1 \text { Oct. }\end{array}$ & 2000 vs 1999 & $\begin{array}{r}\downarrow 21 \% \\
0.8 \text { vs } 1 \\
\end{array}$ & $\begin{array}{c}\uparrow 9.4 \% \\
20.9 \text { vs } 19.1 \\
\end{array}$ & $\begin{array}{r}\downarrow 18.1 \% \\
2.3 \text { vs } 2.8 \\
\end{array}$ & $\begin{array}{c}\uparrow 11.9 \% \\
31.1 \text { vs } 27.8 \\
\end{array}$ & $\begin{array}{c}\uparrow 4.9 \% \\
15.9 \text { vs } 15.2 \\
\end{array}$ \\
\hline $\begin{array}{c}2004 \text { - Athens } \\
13 \text { - } 29 \text { Aug. }\end{array}$ & $\begin{array}{c}1994-2000 \text { vs } \\
1987-1993\end{array}$ & $\begin{array}{c}\downarrow 23.5 \% \\
5.2 \text { vs } 6.8\end{array}$ & $\begin{array}{c}\downarrow 15.8 \% \\
96 \text { vs } 114\end{array}$ & $\begin{array}{l}\downarrow 47.3 \% \\
39 \text { vs } 74\end{array}$ & $\begin{array}{l}\downarrow 13.5 \% \\
64 \text { vs } 74\end{array}$ & \\
\hline $\begin{array}{c}2008 \text { - Beijing } \\
08 \text { - } 24 \text { Aug. }\end{array}$ & $\begin{array}{c}2005 \text { vs 2001- } \\
2004\end{array}$ & & $\begin{array}{c}\downarrow 10.9 \% \\
43.5 \text { vs } 48.9\end{array}$ & $\begin{array}{c}\downarrow 7.7 \% \\
48.6 \text { vs } 52.7\end{array}$ & & $\begin{array}{c}\downarrow 6.9 \% \\
264.3 \text { vs } 283.9\end{array}$ \\
\hline 2012 - London & $\begin{array}{c}2004-2005 \text { vs } \\
2001-2003\end{array}$ & $\begin{array}{c}\downarrow 21 \% \\
0.5 \text { vs } 0.6\end{array}$ & $\begin{array}{c}\uparrow 0.3 \% \\
51.5 \text { vs } 51.4\end{array}$ & $\begin{array}{c}\downarrow 28.9 \% \\
4.8 \text { vs } 6.8 \\
\end{array}$ & $\begin{array}{c}\uparrow 0.5 \% \\
32.5 \text { vs } 32.4\end{array}$ & $\begin{array}{c}\downarrow 4.3 \% \\
27.9 \text { vs } 29.2\end{array}$ \\
\hline
\end{tabular}

third party stakeholders, such as the Ministry of Environment and Physical Planning and Public Works, in preparation for the Games. Athens had hoped that its long term transportation program, since year 1993, would improve air quality. The annual average concentration for year 1994-2000 and 1987-1993 show $\mathrm{SO}_{2}$ was decrease by $47.3 \%$ from 74 to $39 \mu \mathrm{g} \mathrm{m}^{-3}$. The concentration of $\mathrm{CO}, \mathrm{NO}_{2}$ and $\mathrm{O}_{3}$ were reduced by $23.5 \%, 15.8 \%$ and $13.5 \%$ respectively. During the Olympic period Athens also adopted the temporary public transport strategy restricting private and encouraging a park and walk system (www.athens.olympic.org).

For the 2008 Olympic Games, Beijing has adopted the Green Olympic theme and currently invested billions of Yuan to meet the promised improve its environment. A set of tactics have been implemented by the Beijing Municipal Government since 1998. These include a transportation plan that will: replace old buses and taxies to upgrade fuel efficiency and expand the underground with a sustainable route plan. Table 3 shows the annual average concentrations of $\mathrm{PM}_{10}$ have decreased $6.9 \%$ from $285 \mu \mathrm{g} \mathrm{m}^{-3}$ over four years to $265 \mu \mathrm{g} \mathrm{m}^{-3}$ in year 2005. The annual average concentrations of $\mathrm{NO}_{2}$ and $\mathrm{SO}_{2}$ are reduced by:
$10.9 \%$ from 49 to $43.5 \mu \mathrm{g} \mathrm{m}^{-3}$ and $7.7 \%$ from 53 to 49 $\mu \mathrm{g} \mathrm{m}^{-3}$ respectively. As can be seen the programs are in the right direction to improve the air quality (en.beijing2008.com).

The blueprint of future London 2012 Olympic Games introduced sustainable development a the key principle, yet reflecting the usual benefits of growth stimulated by the games. Mayor of London, Ken Livingstone, said: 'Our gift to the Olympic movement in 2012 would include the transformation of one of the most deprived areas of the UK into a revitalised, sustainable 21 st century new urban quarter...' The idea of a Low Carbon Games has emphasised carbon reduction. Improved air quality is driven in two areas: (i) sustainable design to minimise energy demands and manage energy consumption to proof against future climate change and (ii) the investment of public transport infrastructure based on the best available technology. Besides this, the London congestion charging scheme plays an important role in reducing the vehicle emission since the year 2003. Although not all the result of congestion charging, London shows improving air quality. The annual average concentrations for years 2004-2005 and 2001-2003, $\mathrm{CO}, \mathrm{SO}_{2}$ and $\mathrm{PM}_{10}$ decreased by 21,29 and $4.3 \%$ 
respectively. The record also shows the $\mathrm{NO}_{2}$ and $\mathrm{O}_{3}$ concentrations have remained at reasonably the low levels ${ }^{[8,9]}$ in the recent years (www.london2012.org.

London does see itself as implementing significant environmental policies for the games of 2012 that might have a broader context. Minister for Environment, Elliot Morley saw, "(London) taking the initiative to offset carbon emissions arising from the Games and to leave a sustainable legacy of clean energy in developing countries. I look forward to working further with London 2012 in taking this forward in parallel with the Government's own work to offset official air travel emissions from central Government." Sir David King, the UK Government's Chief Scientific Adviser said: “it is very significant that the London 2012 Olympic Bid is taking positive steps to highlight climate change issues in this way... to raise international awareness and help demonstrate practical solutions to the greatest environmental threat of our time."

\section{CONCLUSION}

Many Olympic cities have seen transport strategies as a method of reducing the congestion and air pollution. The opportunity to hold an Olympic Games have been widely seen as a catalyst for a range of urban changing including the implementation of environment policies. The problem is that these changes have not always been maintained at the end of the Games. The strategies have often been narrowly focussed on issues such as energy efficient architecture or the use of safe materials for construction.

Few organizers of Olympic games have grappled with the large costs of international transport related to the Games. The London Olympics planned for 2012 recognise the broader issues although it remains to be seen whether they can live up to their high expectations.

\section{REFERENCES}

1. Witherspoon, K.B., 2003. The 1968 Mexico City Olympic and the politicization of the Olympic Games., The Florida State University, College of Arts and Sciences.

2. Bravo, A.H., 1960. Variation of different pollutants in the atmosphere of Mexico City. J. Air Poll. Control Assoc., 10: 447-449.

3. Bravo, A.H.and Z.R. Magaña, 1979. The actual air pollution situation in Mexico City. StaubReinhaltung Derluft, 39: 427-428.

4. Shephard, R.J., 1984. Athletic performance and urban air pollution. Can. Med. Assoc. J., Vol. 131.

5. Moussiopoulos, N. and S. Papagrigoriou, 2004. Urban Air Pollution Athens 2004 Air Quality.

6. Hao, J., H. Dongquan, W. Ye, L. Fu and K. He, 2000, A study of the emission and concentration distribution of vehicular pollutants in the urban area of Beijing. Atmosph. Environ., 34: 453-465.

7. Friedman, M.S., M.D. Kenneth and E. Powell et al., 2001. Impact of changes in transportation and commuting behaviours during the 1996 summer Olympic Games in Atlanta on air quality and childhood asthma. Am. Med. Assoc., 285: 897.

8. Beevers, S.D. and D.C. Carslaw, 2005. The impact of congestion charging on vehicle emissions in London. Atmosph. Environ., 39: 1-5.

9. Beevers, S.D. and D.C. Carslaw, 2005, The impact of congestion charging on vehicle speed and its implications for assessing vehicle emissions. Atmosph. Environ., 39: 6875-6884. 